\title{
Identity Politics: a Study of the Historicity Politics Identity of the Hadrami Community
} in Indonesia

\author{
Bagus Prayogi ${ }^{1}$, M. Khoirul Hadi Al-Asyari ${ }^{2}$ \\ 1,2 IAIN Jember \\ baguspr39@gmail.com
}

\author{
Submission Track: \\ Received :2020-08-31 \\ Final Revision : :2021-09-14 \\ Available Online : 2021-12-01
}

\begin{abstract}
The community of Arab descent in Indonesia is a marginalized or minority community. In addition, they are also the least studied community in Indonesia. Many non-Arabs do not know that most of the Arabs in Indonesia are Hadrami people who come from Yemen and not from the original Arabs or Hejaz. Most Indonesians are also unaware of the significant social and cultural differences between countries in the Middle East region, particularly with regard to the history of internal relations within the Hadrami community in Indonesia. The Hadrami people come to Indonesia with several motivations, namely getting a better life, getting away from criminal and civil problems, the existence of conflicts and wars in their place of origin and so on. Different backgrounds in terms of culture and social become a problem. These cultural and social differences make it difficult for them to adapt and acculturate to indigenous peoples. Even so, they are still looking for a balance point in order to become part of the indigenous community. For example, they marry native women and men. This accommodation process is experienced by many other diaspora communities, which is always accompanied by pressure due to the increasing number of mixed-breed populations in their communities. In the book entitled, Seeking Identity, the internal relations between Arabs as immigrant communities and their external relations with the wider community are explained, including the top level authorities, namely the government, during the Dutch East Indies, the Japanese occupation and the Republic of Indonesia. This article deals with the history of identity by using research materials which are dominated by library materials. The title raised is Identity Politics: Historical Studies of the Identity Politics of the Hadrami Society in Indonesia. There are three questions in this article. First, what is the identity and identity politics of the Hadrami people in Indonesia. Second, what is the history of the Hadrami people in Indonesia. Third, what is the history of the Hadrami community's identity politics in Indonesia. This paper uses an analytical context approach to explain the concept of identity and identity politics. In addition, the purpose of this article, namely: 1). knowing the identity and identity politics of the Hadrami community in Indonesia; 2). knowing the history of the identity politics of the Hadrami people in Indonesia; and 3). knowing the identity politics of the Hadrami people in Indonesia.
\end{abstract}

Keywords: identity, identity politics, hadrami people. 


\begin{abstract}
Abstrak
Kemunitas keturunan Arab di Indonesia merupakan komunitas yang terpinggirkan atau minoritas. Selain itu, mereka adalah komunitas yang paling sedikit dikaji di Indonesia. Banyak orang non-Arab yang tidak mengetahui bahwa kebanyakan orang Arab yang berada di Indonesia adalah masyarakat Hadrami yang berasal dari Yaman dan bukan dari Arab asli atau Hejaz. Kebanyakan masyarakat Indonesia juga tidak mengetahui perbedaan yang signifikan di bidang sosial dan budaya antara negara-negara di kawasan Timur Tengah, khususnya yang berkaitan dengan sejarah hubungan internalnya dalam komunitas Hadrami di Indonesia. Masyarakat Hadrami datang ke Indonesia memiliki beberapa motivasi, yaitu mendapatkan kehidupan yang lebih baik, menyingkir dari masalah pidana dan perdata, adanya pertikaian dan peperangan di tempat asal dan sebagainya. Latar belakang yang berbeda dari segi budaya dan sosial menjadi masalah. Perbedaan budaya dan sosial ini menyebabkan mereka sulit untuk beradaptasi dan berakulturasi dengan masyarakat pribumi. Sekalipun demikian, mereka tetap mencari titik keseimbangan agar bisa menjadi bagian dari masyarakat pribumi. Misalnya, mereka menikah dengan wanita maupun laki-laki pribumi. Proses akomodasi ini banyak dialami oleh komunitas diaspora lain, yang mana selalu disertai dengan tekanan akibat meningkatnya jumlah populasi keturunan campuran dalam komunitasnya. Dalam buku yang berjudul, Mencari Identitas dijelaskan hubungan internal sesama orang Arab sebagai masyarakat pendatang maupun hubungan eksternalnya dengan masyarakat yang lebih luas, termasuk dengan otoritas tingkat atas, yaitu pemerintah, baik masa Hindia Belanda, pendudukan Jepang dan masa Republik Indonesia. Artikel ini berkaitan dengan sejarah identitas dengan menggunakan bahan riset yang didominasi oleh bahan Pustaka. Adapun judul yang diangkat, yaitu Politik Identitas: Studi Historitas Politik Identitas Masyarakat Hadrami di Indonesia. Ada tiga pertanyaan dalam artikel ini. Pertama, bagaimana identitas dan politik identitas masyarakat Hadrami di Indonesia. Kedua, bagaimana sejarah masyarakat Hadrami di Indonesia. Ketiga, bagaimana sejarah politik identitas masyarakat Hadrami di Indonesia. Tulisan ini menggunakan pendekatan konteks analisis untuk menjelaskan bagaimana konsep identitas dan politik identitas. Selain itu, tujuan dari artikel ini, yaitu: 1). mengetahui indentitas dan politik identitas masyarakat Hadrami di Indonesia; 2). mengetahui sejarah politik identitas masyarakat Hadrami di Indonesia; dan 3). mengetahui politik identitas masyarakat Hadrami di Indonesia.
\end{abstract}

Kata kunci: identitas, politik identitas, masyarakat Hadrami.

\title{
INTRODUCTION
}

Arab communities in the Dutch East Indies are widely known as traders and pioneers in the spread of Islam. Little is known about the Arabs living in Indonesia. This is due to the lack of research on the Arab community. In addition, the Arab community is a group that tends to be culturally closed because they think that their culture must be preserved wherever they are. This is the reason the author raised this theme, which is intended to be a guide for other writers. Several reports on Arab activity in the Dutch East Indies relate mostly to the spread and development of Islam. Arabs are the second most important community in Indonesia after the Chinese. Like most other communities, over time the number of Arabs is increasing 
and most of them have a purpose to trade. They also have long participated in developing the economy in the Dutch East Indies. However, little is known about these Arabs. There is even a prejudice against them. For example, accused of being involved in unfair competition, usury practices, forming associations with protection, bribery, and prioritizing members of one's own group. However, open hostility is very rare. The reason for this lack of hostility can be found in the small Arab community and in their national and religious identity.

A question arises, where did these Arabs come from? Are they from the original Arabs (Hejaz) or the Arabs in South Yemen (Hadrami)? The Arab community in the Dutch East Indies or until now in Indonesia is a nation that comes from the Hadramaut community of Yemen. The first time they went to the Dutch East Indies was around the 10th century, which was increasing in number over time. The origins of the Arabs in Indonesia are mostly from Yemen or Hadrami. Most people don't know this, and think that Arabs are all the same, but in reality, they have very significant and fundamental differences. Then what is the difference? Many theories have been used to explain the migration of the Hadrami people. One of them, namely the theory of stress and needed. In this theory, it is explained that a people's migration is determined by the needs and pressure factors. If human needs are met, then there will be no movement to another place, but if human needs are not met, then there is pressure to meet the needs of life, causing them to move from one place to another. In this regard, David Mcclelland said that the main factor that moves people to progress in all fields, including the economic sector is desire. Human desires will also change if influenced by the economy from outside or it can be said that there is contact with the economy from outside, because their needs cannot be met by their own region ${ }^{1}$. According to Uka Tjandrasasmita, Arabs coming to the archipelago cannot be separated from economic factors, namely looking for new types of livelihood as traders. This activity was followed by the spread of Islam ${ }^{2}$.

The spread of the Hadrami people throughout the world was further expanded with the opening of the Suez Canal in 1869. In Indonesia, in the 19th century their number had reached 621 Moorish Arabs living on the island of Java. Some of them are traders and religious leaders. As a result of the opening of the Suez Canal in 1870 and 1900, the number

\footnotetext{
${ }^{1}$ Kuntowijoyo, Metodologi Sejarah (Yogyakarta: Tiara Wacana, 1994), 92.

${ }^{2}$ M.C. Ricklefs, Sejarah Indonesia Modern (Yogyakarta: Gadjah Mada University Press, 1991), 3.
} 
of minorities in the Dutch East Indies increased from 13,000 to 27,000 ${ }^{3}$. In 1920, the Arab community increased to 45,000 members, and in 1930 to 71,335 . In addition, by the time of the Japanese occupation the Hadrami Arab community had reached 80,000 people. The settlements of Arabs in Indonesia are centered on the coast. Many reports say that the majority of the livelihoods of these Arab communities are traders ${ }^{4}$. Many Arab communities who are Muslim live in Arab neighborhoods or better known as Arab Villages. Likewise with other communities that have special residences with almost the same designation, such as Chinese Village, European Village and so on.

The destination of the Arabs at the time of migration was Aceh and Singapore. Then they spread to several other cities, such as Pontianak, Palembang and Java. Arabs settled on the island of Java in the 1830s. In addition, they came to eastern Indonesia in the $1870 \mathrm{~s}$. The occupation of Singapore by the British in 1819 and major advances in trade changed the Arabs' goals from Aceh to Singapore. Since 1860, after the opening of the Singapore-bound steam ship, Aceh was no longer the main destination for migration ${ }^{5}$. In Java there are also large settlements of Arabs, such as in Batavia, Pekalongan, Cirebon and Surabaya. The settlement of Arabs in Surabaya is a migration from Gresik. The following is a map of the migration journey of the Hadrami people to Indonesia:

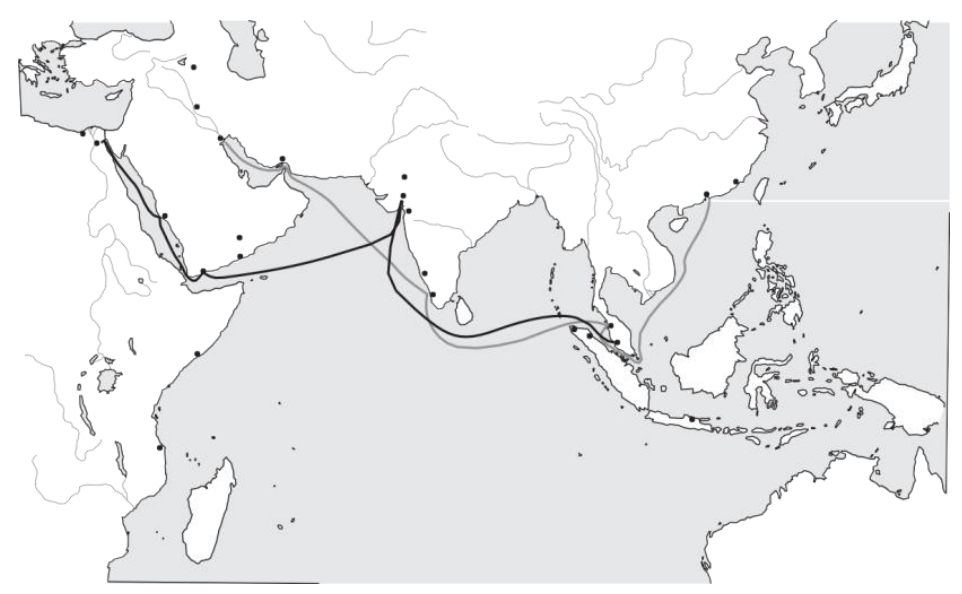

Figure 1. Hadrami Community's Journey to Indonesia.

Source: Enseng Ho, The Graves of Tarim Geneology and Mobility Across the Indian Ocean ${ }^{6}$.

\footnotetext{
${ }^{3}$ J.M van der Kroef, Indonesia in the Modern World, vol. 1 (Bandung: Mas Baru, 1954), 250.

${ }^{4}$ W.F. Wertheim, Masyarakat Indonesia dalam Transisi, Studi Perubahan Sosial (Yogyakarta: Tiara Wacana, 1999), 65-67.

${ }^{5}$ L.W.C Ivan den Berg, Handramut dan Koloni Arab di Nusantara (Jakarta: Seri INIS, 1989), 72.

${ }^{6}$ Engseng Ho, The Graves of tarim geneology and Mobility Across the Indian Ocean (California: California Press, 2006).
} 
Hadrami society is characterized by a fairly rigid and hereditary class structure. In the 15th century, many Arabs were found in every archipelago in Indonesia. Some Arabs have managed to exert a great deal of influence in the region. The various Islamic trading countries, which arose on the north coast of Java in the 16th century, were ruled by Arabs. At the end of the 18th century, Arab wealth hunters succeeded in establishing their own state in Sumatra and Kalimantan. The Arabs did not merely spread religious ideas, such as opponents of usury and moneylenders. The practice of such activities is contrary to the mission of their arrival, which is to spread the religion of Islam. Even so, the religion of Islam did not only come from them, but also from the top brass of this country who went to study in Arab countries first. In addition, the Muslim community does not always come from Arab, but from other nations who also adhere to Islam ${ }^{7}$. As an illustration, it can be mentioned that some Arabs practice usury, which is strictly prohibited by religious rules. Van Der Berg's report is very clear and illustrates how the Arabs practiced it in the Muslim community ${ }^{8}$. Such conditions have given the answer that religion is not always influential and related to economic activity ${ }^{9}$.

Arabs are generally accepted in the places where they live because of their religious similarity with the natives. However, the two actually have different cultures. Even so, little by little cultural mixing is inevitable. Most of them got native wives. From here that there is a mixture of descendants with natives. However, nowadays Arabs rarely marry the natives. They prefer to marry of the same race. The goal is to preserve the culture. This accommodation process, as experienced by many other diaspora communities, is always accompanied by pressure due to the increasing number of mixed ancestry population in their communities. To a certain extent, the descendants in the mix (the Muwallads) become "estranged" from their ancestral land and become closer to the land where they were born and raised. The process of forming the identity of the Hadrami community, which is still characterized by this rigid class structure, has resulted in serious disputes, especially between the first generation migrants (wulaiti) and those who have settled, as well as between conservative and progressive groups. In the process of defending and searching for

\footnotetext{
${ }^{7}$ Uka Tjandrasasmita, Pertumbuhan dan perkembangan Kota-Kota Muslim di Indonesia (Kudus: Menara Kudus, 2000), 23-28.

${ }^{8}$ Berg, Handramut dan Koloni Arab di Nusantara, 87-89.

${ }^{9}$ Bambang Purwanto, "Merajut Jaringan di Tengah Perubahan: Komunitas Ekonomi Muslim di Indonesia pada Masa Kolonial,” Yogyakarta: Fakultas Sastra UGM, 2000, 48-74.
} 
it, all social defects and polemics, even conflicts, are involved. Internal struggles and conflicts are almost unknown to many outside them, leading to significant identity changes in a relatively short period of time. Nevertheless, it can be said that the identity of the Hadrami community has not disappeared, but more and more community members have had their identities filled with newer or different components than before.

\section{DISCUSSION}

\section{Identity and Identity Politics Of The Hadrami Community}

Identity in the big Indonesian dictionary is the characteristics contained in the self or the characteristics contained in the identity of a person or nation that is not owned by others. Identity is in the individual as well as in his identity. According to Koento Wibisono, the notion of identity is essentially "a manifestation of cultural values that grow and develop in aspects of a nation's life, and with these distinctive characteristics, a nation is different from other nations in its life". Identity according to Stella Ting Toomey is a self-reflection that comes from family, gender, culture, ethnicity and the process of socialization. Identity basically refers to ourselves and other people's perception of us.

Identity politics is a boundary that exists to clarify the boundaries between original individuals and individuals resulting from mixed marriages which have a permanent nature. In simple terms, identity politics is a red line or barrier between the original individual and the mixture of the results of the marriage. According to Agnes Heller and Donald L. Morowitsz, the red line is identity politics which means difference. So, identity politics are the politics that are used to seek social recognition with several fields being the main point of their existence to be recognized, such as the economic and political fields carried out by certain communities or carried out by certain communities to support achieving goals. Meanwhile, according to Kemala Chandakirana, identity politics is politics used by leaders as political rhetoric as "we" for "original people" who want power and "them" for "immigrants" who must give up power. Identity politics are manipulated to fulfill economic and political interests of the community of those who have an interest. However, over time, Kemala's theory regressed because he said that in identity politics, of course, ethnic ties played an important role. They become potent cultural symbols, as well as a source of power for political action. The understanding of Kemala's opinion has a tendency; 1). Want to get 
the recognition and treatment that is equal to or basic human rights, whether political, economic or socio-cultural; 2). In order to maintain and preserve the cultural values that characterize the group concerned; 3). Strong loyalty to their ethnicity. Klaus Van Boyment also explains the same thing, but more to the characteristics of the identity politics movement which basically rebuilds the "big narrative" which they reject in principle and builds a theory that controls the biological factors that make up the basic differences as the reality of life. In one identity politics movement there is a tendency to build a reverse apartheid system. When power is not achieved properly and power-sharing is not achieved as the goal of the movement, then the only way out is exceptional.

The identity of the Arabs does not want to lose their culture in Indonesia. Until long after the turn of the century, the majority of Arabs in Indonesia identified with their home country. This situation is caused by the continuous flow of wulaiti, newcomers or fullblooded Arabs who come to Indonesia, the relationship of immigrants with those who live in their hometowns, and the "temporary" nature of migration. However, other factors reinforce Arab identity, such as continued discrimination by colonial authorities, political developments in the Arabian Peninsula, and pan-Islamism. The status of the foreign east is a thorn in the flesh for the Arab community. This status not only hinders the further development of trade, but also hurts their self-esteem. They feel relegated to the level of second-class society. There have been constant protests, especially by sayids against the settlement policy, the process of obtaining a travel permit which takes a long time, and checking of letters on the road is seen as demeaning the sayid. As a result, the sayids pleaded with the Turkish government and the British government that they would try to change the colonial mind from gaining European status. Snouck Hurgronje supports their objection to the travel restrictions. Snouck repeatedly complained in his recommendations to the governor-general about the colonial authorities' "unpleasant" and "illegal" treatment of these residents ${ }^{10}$. The civilians were too authoritarian towards the Hadramis, such as restricting immigration to Indonesia. With civil authoritarian power that is carried out in order to overcome the spread of Islam and pan-Islamism. According to Snouck, the development of pan-Islamism and the wider spread of Islam would result in fanaticism that could undermine the power of the Dutch East Indies government. Snouck's suggestion was heeded by the

${ }^{10}$ E Gobee and C Adriaanse, Ambtelijke adviezen van C. Snouck Hurgronje, 33, 34, 35 ed., vol. I, II, III (Den Hagg: Martinus Nijhoff, 1957), 566. 
authorities. They did restrict immigrants from going to Indonesia. They provide restrictions and conditions that must be met in order to enter. If they cannot meet the requirements, then they cannot enter Indonesia at that time. Because of the rules applied by the authorities, the Arabs protested which resulted in 1919 the authorities reopened the tap for immigrants to enter Indonesia, which at that time was still called the Dutch East Indies.

At the turn of the 20th century and the Japanese invasion of 1942, Arabs in Indonesia underwent important changes in social and national identification. The rigid and hierarchical socio-cultural order of Hadramaut has been largely torn down. The relatively isolated Arab community has become more open to developments in Indonesian society at large. More and more Arabs are realizing that Indonesia is not South Arabia, and that Indonesia has become their homeland. Until the 20th century, for the most part, Arab immigrants identified with Hadramaut. It is certain that they have settled in the Indonesian archipelago, either temporarily or permanently, but in principle they have only economic and family ties to their new environment. As Arabs and Muslims, their main involvement is with the development of their own country, their homeland, and with the Arab world in general. Interest in developments in local Indonesian society is limited to the economic field. Like so many other immigrants from Asia and Europe, they saw their new environment as a place to make money. This orientation was reinforced by the Dutch colonial policy. Policies on immigration, regulations on travel and residence, and separate laws for Foreign Easterners made Arabs feel hostile to the colonial government. This perception continued until discriminatory decisions on migration and resettlement were overturned in 1919.

The dispute that was most clearly seen in 1912-1934, this commotion as a result of a title fight, hasn't only become a symbol of the social tension of Arab community life, but also became the issue of who was most important. The winner of this battle will be the winner of the social struggle, the colonial government itself claims that no one can mediate on this issue. The Sheikh emerges victorious in the moral or title fight. The Sheikh was able to get out of Sayid's suffocating shackles. From here the traditional social order ends and a new identity is formed. The title battle not only changed the identity of the Hadrami people in Indonesia, but also brought about no small problem in the sense of Arab national identification. This problem is getting bigger and bigger. Conflict is unavoidable between the sheikh and sayid. For the Arab minority, viewing Indonesia as their homeland is haram. So far they have never discussed this. It was only after this oath was made in October 1934 
that this issue became a topic of discussion. Until now, that date is remembered as the day on which Arabs became aware of their Indonesian identity.

The sheikh in particular has been emancipated in a social sense. They are increasingly aware that as far as national feelings are concerned, they are closer to Indonesia than they are to Hadramaut, their place of origin, but without giving up their Arab consciousness. In other words, they have identified themselves with where they live. In addition, not unlike the Sayid group, more and more people are voicing to accept Indonesia as their homeland. The younger descendants in particular, who are like the young sheikh, feel alienated from their home country. From this, the realization grew that they could no longer live with two homelands. However, sayid old or full-blooded sayid still identifies with Hadramaut, especially because of the loss of his special position. In 1930 the average Hadrami people already recognized Indonesia as their homeland. In addition, they also sympathize with the nationalists. This awareness emerged as a result of the activities of PAI, which worked closely with various pro-nationalist organizations. PAI succeeded in breaking down barriers to identifying Indonesia as their homeland. They have also succeeded in strengthening ties with both indigenous and non-indigenous people and becoming aware of their position.

\section{The History of The Hadrami People in Indonesia}

The Hadrami community is a community originating from Hadramaut (Yemen). They are not from Saudi Arabia (Hejaz). The Hadrami community is very closed. They are closed because they do not want their culture to be mixed with other groups. Hadrami society is characterized by a fairly rigid and descent -based class structure. The highest class is the Sayid who claims to be a descendant of the Prophet Muhammad through his grandson, Hussein. They are also called Ba'alawi or Alawi, the ancestral grandson of their clan, Ahmad bin 'Isa (the Emigrant), who more than 1,000 years ago moved to Hadramaut from Basrah in Iraq. Sayid was a religious nobleman in Hadramaut. They occupy special positions, are always unarmed, and perform important religious and social duties, such as overseeing obedience to religious obligations, leading activities and ceremonies, and building Islamic education. Prior to the establishment of the People's Republic of South Yemen, they acted as mediators of peace between the disputing parties and provided roadmaps to pass through enemy territory. People kissed Sayid's hand as a salute and made a pilgrimage to Sayid's holy tomb. Because of the sayid's isolation in Hadramaut, the sayid saw himself as a purer line of 
nobility than the descendants of the Prophet Muhammad in other countries. In addition to the spiritual, educational, and political functions, sayid is also involved in economic activities. They owned land and traded.

Under the sayid there are two groups that occupy the middle layer of society: the sheikh and the qobili. Both groups claim to be descended from Qahtan, the ancestor of all southern Arabs. The sheikh has a higher status than the qobili. The sheikh is a religious elite adli Hadramaut, descendants of theologians, and wise men who carry out the same tasks as sayid. However, because he was smaller than sayid, the sheikh lost to the group of descendants of the Prophet. Like sayid, the sheikh is partially or fully involved in worldly affairs. Members of the tribe are known as qobili. Each tribe had its own territory, which at least until the pacification of Hadramaut was fiercely defended. Tribal members form armed forces. Despite their lower status, the qabili were actually the true rulers of Hadramaut. AlKathiri and al-Quaity belong to this group.

At the lowest social strata, there are Masakin and Da'fa, namely those whose origins are not important, they consist of traders, merchants, laborers and servants, and in ancient times were slaves. This group consists of tribes who were captured or because they lost the war. Slaves are often oppressed workers and are in a weak position, so that exploitation of this group in the form of forced labor often occurs. Until the 1970s, as far as is known, the boundaries between the four classes were strictly guarded in Hadramaut and were expressed mainly in the rules of arranged marriages. It is said that a woman must marry a man who is not lower in rank than her, and for a man it is okay to marry a woman who is below him. Because the lineage or nasab lies in men. The first indications of Arabs are visiting maritime Southeast Asia date back to the 10th century. In the following centuries, their numbers gradually increased. Either way, Arabs traded and contributed directly to the spread of Islam. In the 15th century, small Arab communities could be found in the Indonesian archipelago. Some Arabs managed to exert a lot of influence in these areas. The various Islamic trading countries, which arose on the north coast of Java in the 16th century, were ruled by Arabs. At the end of the 18th century, Arab wealth hunters established their own states in Sumatra and Kalimantan.

Since 1869, voyages using steamships between Europe to Arabia have experienced rapid development due to the opening of the Suez Canal. Furthermore, the European ships headed to Southeast Asia, especially to the Archipelago. The intensity of shipping and the 
easier it is to reach Indonesia by European steamship shipping from Arabia has an effect on the quantity of Arabs in Indonesia. This development can be seen from data at the beginning of the 19th century, namely there were about 621 Arabs and Moors living in Java as traders and religious leaders. The Arabs were spread in almost all bustling cities in Java, including in Surabaya. Then, between 1870 and 1900 the Arabs in Indonesia increased from 13,000 to 27,000. In 1920 there were 45,000 Arabs in Indonesia. In 1930 it increased again to about $71,335^{11}$. The data clearly show that the high number of shipping using steamships from Europe that goes through the Europe-Arab-India-Southeast Asia route (Aceh and Singapore) has a major influence on the migration of Arabs to Indonesia in search of a new life and homeland. Those who made the move were mostly from Hadramaut ${ }^{12}$.

The settlements of Arabs in Indonesia were centered in areas around the coast. There are reports that most Arabs work as traders ${ }^{13}$. Arabs and other Muslim communities usually inhabit areas called Arab villages. These people can be found in the center the kingdoms of Banten, Surabaya, Semarang and Batavia. These cities developed into trading centers and were visited by traders from various countries. The villages formed in these cities were usually based on their area of origin, so they did not know people from Indian villages, people of Pegu, Siam, Persi, Arab, Turkish and Chinese. There are also merchant villages of the Indonesian people who come from various regions, namely the Malay villages, Ternate, Banda, Banjar, Bugis and Makassar villages. Villages based on ethnicity are also found in several cities in Indonesia, which are trade-oriented, such as Makassar, Batavia, Semarang, Banten and Surabaya ${ }^{14}$. The economic activity of the Arabs started from the bustling cities and then spread to the interior to form new economic communities.

The journey from Hadramaut to the Archipelago lasted for months. The first time the Arabs traveled must depart from a-Mokalla or ash-Shihr to Bombay. Then to the island of Ceilon (Srilanka), then to Aceh or Singapore, which is done by using a sailing ship. Wealthy Arabs traveled to Indonesia via Aden and headed straight for Singapore by steamboat, thus

\footnotetext{
${ }^{11}$ See: Kroef, Indonesia in the Modern World; Volkstelling, Chineezen en andere Vreemde Oosterlingen In Nederlandsch-Indie, vol. VII (Batavia: Lansdkrukkerij, 1930).

${ }^{12}$ Kroef, Indonesia in the Modern World, 1:167.

${ }^{13}$ Wertheim, Masyarakat Indonesia dalam Transisi, Studi Perubahan Sosial, 65-67.

${ }^{14}$ J.C. van Leur, Indonesian Trade and Society, Essay in Asia Social and Economic History (The Hague: van Hoeve Publisher Ltd., 1967), 13; Wertheim, Masyarakat Indonesia dalam Transisi, Studi Perubahan Sosial, 60-61.
} 
making their way to Indonesia easily ${ }^{15}$. The first destinations for the Arabs were Aceh and Singapore. Then they spread to Pontianak, Palembang and Java. Arabs began to settle in Java around 1870. The British occupation of Singapore in 1819 caused the place to experience great progress in trade. As a result, Singapore replaced Aceh's position as a destination for Arab immigrants. Since the opening of steamship shipping in the 1860 s with the Singapore-Arab route, Aceh has ceased to be a destination for Arab immigration ${ }^{16}$. In Java there are six major Arab settlements, namely Batavia, Cirebon, Tegal, Pekalongan, Semarang and Surabaya. The Arabs in Surabaya were originally people who migrated from Gresik $^{17}$.

Most of these Arabs are from Hadramaut, a region in South Yemen, which in 1990 merged with North Yemen to become the Republic of Yemen. Meanwhile, some of them came from the Hejaz, the region where Mecca and Medina are located. The Hadramis came to trade, while the Arabs traveled back and forth to the Indonesian archipelago to take people on pilgrimages. Initially, some of the immigrants, almost all of whom were men, did not plan to settle in the archipelago. They want to get money quickly to help poor relatives or save for a better future. Huge sums of money are sent home every year. Although many returned, most of the immigrants remained in the archipelago. Most of these young immigrants married in their new environment, so that their return was hampered. In the early 19th century, most of them married local women, but later they married the descendants of the mixed husband and wife, muwallad or Arab peranakans. Many immigrants preferred a secure life in the Dutch East Indies to an uncertain future in Hadramaut. Because of good sea relations with South Arabia, especially before World War II, many of them were allowed to return to their homeland for a long or short period of time. Some immigrants, even have a second home or second wife there. At that time, sending children to Hadramaut for several years to get a good education was not something that was not uncommon.

Hadramaut is an arid mountainous region. Until the 20th century, Hadramaut was a remote region. At the beginning of the century, the journey by foot from the most important port cities of Makalla and al-Shihr to the relatively densely populated wadis in the interior took five to eight days. Tribal wars, family feuds, crime and robbery have made the region

\footnotetext{
${ }^{15}$ Berg, Handramut dan Koloni Arab di Nusantara, 80.

${ }^{16}$ Ibid., 72.

${ }^{17}$ M. Habib Mustopo, Kebudayaan Islam di Jawa Timur, Kajian Beberapa Unsur Budaya Masa
} Peralihan (Yogyakarta: Penerbit Jendela, 2001). 
unsafe. The majority of the population work as farmers. In order to survive, most of the male population is forced to find work elsewhere. In the 19th century, they went to India, East Africa, and the countries around the Red Sea. However, after the turn of the century, the Dutch East Indies and English Channel settlements became the most important destinations. In 1934, about a quarter of all Hadramis lived outside Hadramaut, with their largest colony being in the Dutch East Indies. This is evident from the reports of Europeans who traveled into the heart of Hadramaut. Everywhere they met people who had lived in Java for some time and spoke Malay, or had family in Java. Many people receive remittances from Java on a regular basis. In an area where most of the population is poor, there are people who live in stately homes or palaces, which are financed by income from migrant work. Some households have Javanese or Chinese maids or cooks.

Before the state of South Yemen was founded in 1967, Hadramaut was not a political entity. Over the centuries, the region has been the scene of rivalry between different kingdoms, autonomous cities, and tribes. Despite considering Hadramaut as part of the caliphate, the Ottoman sultans never established any real authority there. According to Snouck Hurgronje, a Dutch scholar who specializes in Islam and who was also an adviser to the Dutch colonial government on Arab affairs, the Turkish governor would only be able to defend himself in the den of factionalism through constant displays of power, and there was a constant revolt against the Turkish government. In the 19th century, British influence increased in South Arabia. The British occupied Aden in 1839, and in the last quarter of the century made treaties with kings and tribal leaders. After a diplomatic treaty with Turkey in 1904, Britain acquired what is now South Yemen. The decline of the trade sector during the depression of the 1930s had an effect on the Arab economy. This influence is manifested in the search for new areas that provide economic benefits. The destinations for the Arabs who migrated from East Java were Semarang and Batavia. The rich Arabs, on the contrary, went on a pilgrimage to Mecca.

Arabs are an ethnic minority, as are Chinese and Europeans. The three ethnic groups have differences, especially in the control of important economic resources. The activities of the Arabs in the Dutch East Indies were often different from the principles of their religion, especially in terms of usury. Usury for Muslims is unlawful. Nevertheless, the Arabs continued to apply it in trading in the Dutch East Indies. This practice, according to the government, is so burdensome to indigenous people. Therefore, the Dutch East Indies 
government tried to overcome this. However, it didn't work. The target of usury is the indigenous people. Indigenous people can actually borrow money at low interest rates from other ethnic groups outside of Arabia. However, Arabs are good at attracting victims by providing various facilities. Such activities for the natives are considered things that can save them from bankruptcy for a while, although the requirements that must be met are severe $^{18}$. This activity is also carried out by ethnic Chinese against natives.

The report by L.W.C van den Berg says that there is another livelihood activity for the Arabs, namely retail sales by installment method. The Arabs who practice this way of trading are not rich Arabs. Usually such Arabs sell their goods in retail to passersby, while smoking a pipe in front of the door and generally such Arabs do not have a shop. Wealthy Arabs used to own shops and retail goods in their shops and sell their goods in other cities. In addition, the merchandise is usually sold using a peddler pattern, either at their own risk or by the vendor who bears it. In this way, the vendor earns $2.5 \%$ to $5 \%$ of the profit earned or the owner of the goods receives the merchandise on condition that the goods are returned or pay the agreed sale proceeds. If the vendor succeeds in selling the goods above the price, then the excess profit belongs to the vendor. The peddler prefers to sell his wares among the indigenous people at high prices in installments ${ }^{19}$. The main commodities in the trade of the Arabs were cotton and Indian cotton. The second commodity traded is diamonds, gemstones, various commodities imported from Europe, such as gold and silver goods, watches, preserved food, pottery, and various metal goods. The role of Arab traders actually benefited the natives, because they became intermediaries for the Europeans and the Chinese, especially the commodities produced by the natives, which would then be marketed to Chinese or European traders ${ }^{20}$.

Reports from G. H. von Faber say that the cloth trade was carried out from India. In addition, adhesive fabrics and German fabrics are also sold. Arabs became wholesalers at European import firms. This business is often seen as a rival to the monopoly of Chinese traders. Another activity of Arab traders was trading in building materials (leveransir). They also import horses from the island of Sumba and their woven fabrics. The Arabs also ran a small tile factory, a printing press, and a cinema business. In Surabaya, the Arabs controlled

\footnotetext{
${ }^{18}$ Berg, Handramut dan Koloni Arab di Nusantara, 135.

${ }^{19}$ Ibid., 92.

${ }^{20}$ Ibid., 93.
} 
1000 wagons, although not a proud source of economy, but this business has become new jobs for thousands of indigenous people and has strengthened the bond of interaction between the indigenous group and the Arabs ${ }^{21}$. The involvement of people of Arab descent in Indonesia's political history was marked by the establishment of the Indonesian Arab Party (PAI), which is considered by some to be part of the community's love for the new homeland (Indonesia). In addition, the Arab community feels that they are an inseparable part of the indigenous people because of their religious similarities ${ }^{22}$. The pledge of the Arabs as below reflects the strength of the conjecture and justifies the argument.

"Indonesia, the symbol of my unity

Indonesia, the land where I was born

The unity of the Arabs in Indonesia is getting brighter, we remain loyal"23.

Based on the description above, it can be said that the birth of the PAI, which marked the period of the national movement was inseparable from the desire of the Arab community to unite without any divisions or groups with the indigenous population. The recognition of the Arab community as part of this is of course intended so that they can gain a position in the political arena in Indonesia. Changes that occur in the social order of Arab society, at least, are the role and figure of Arabs who are respected by indigenous people compared to their home countries. This position is a bridge for Arabs to socialize and have kinship relations with local residents, especially in Surabaya. Therefore, the relationship is easier to do with the people of Surabaya, both economically and socially, so that the continuity of adaptation continues to be carried out and maintained, although in some cases the two communities are not always harmonious due to cultural differences.

An important note in the period of the 1920s in the Indonesian economy was the development of the people's economy, both because of the increase in commodity production and the boom in that period. This is evidenced by the increasing number of pilgrims who

\footnotetext{
${ }^{21}$ G.H. von Faber, Nieuw Soerabaia, de Koopstand in de eerste Kwarteetuw Sadert Haren Instelling, 1906-193 (Soerabaia: N.v. Boekhandel en Drukkerij II, van Ingen, 1993), 81-82.

${ }^{22}$ Hamid Algadri, Politik Belanda terhadap Islam dan Keturunan Arab di Indonesia (Jakarta: C.V. Haji Masagung, 1988).

${ }^{23}$ Ibid.
} 
went to Mecca during that period ${ }^{24}$. In addition to performing the pilgrimage, some Arabs also took part in deepening the knowledge of Islam in Mecca and Medina, as has been done by Daid Abdullah bin Abdurrahman bin Mochammad Ganeman, an Arab with the rank of lieutenant who lives in Gresik. Hadrami society is very closed, so many other groups do not know about their group. They are closed because they don't want their culture to be mixed. This continued until Indonesia's independence. The government has contributed to this situation. During Abdurrahman Wahid's presidency, Arabs changed their legal status to become Indonesian citizens, not "Indonesian citizens, not natives".

The existence of Arabs (Islam) in the Dutch East Indies was always associated with radical movements by the Dutch East Indies government. This is related to the large number of Muslim community groups who fought against the policies of the Dutch East Indies government in several areas in Indonesia, such as what happened in Padang (Padri War), Central Java (Diponegoro War), and the Aceh War in $A_{c e h}{ }^{25}$. In the introduction to the book, L.W.C van den Berg stated that research on Arab community activities was carried out as an effort by the Dutch East Indies government to find out more quickly, whether or not there were dangerous elements in Arab society, especially those related to the threat of Pan-Islamism. The fact shows that in Arab society, there are no harmful elements. The Arabs are not a latent danger, so they need not be watched. Arabs are often obedient in practicing their religion, but do not propagate their religion by force or fanaticism ${ }^{26}$.

\section{The Identity Politics of The Hadrami Community}

The identity politics of the Hadrami community began with the formation of the Indonesian Arab Party (PAI). The Indonesian Arab Party is considered by some as a form of the Arab community's love for their homeland. In the process of forming this party, many events occurred. A very big event occurred in Semarang on October 4, 1934. Thirty-nine Arab youths consisting of sayids and sheikhs who were born in the Dutch East Indies stated that they did not see Hadramaut as their homeland, but Indonesia as their homeland. These progressive youths vowed that as sons of Indonesia they would fight for the territory and

\footnotetext{
${ }^{24}$ Purwanto, "Merajut Jaringan di Tengah Perubahan: Komunitas Ekonomi Muslim di Indonesia pada Masa Kolonial," 48-74; Jaroen Touwen, Extremes in the Arcipelago, Trade and Economic Development in the Outer Islands of Indonesia, 1900-1942. (Leiden: Rijksuniversiteit, 1997), 40-41.

${ }^{25}$ Sartono Kartodirdjo, Sejarah Indonesia Baru, 1500-1900: dari Emporium sampai Imperium, vol. I (Jakarta: Gramedia, 1992).

${ }^{26}$ Berg, Handramut dan Koloni Arab di Nusantara, xix-xxiii.
} 
people of Indonesia. After the pledge was made, they established the Indonesian Arab Party (PAI). This union explicitly opposes the division of the Arab community and seeks to increase cooperation and solidarity among Indonesian Arabs.

They also wanted to free Indonesian Arabs from Hadrami social relations and integrate them into Indonesian society. Therefore, they want to eliminate the use of the title sheikh among themselves and use Malay as their language of communication ${ }^{27}$. The founder and leader of PAI are A.R. Baswedan. Baswedan fought for the emancipation of the Arab community and its integration into the wider Indonesian society. Baswedan struggled to spread his ideas in pro-nationalistic newspapers. He fought against the dominant notion among Arabs that Indonesia was only a temporary residence and criticized full-blooded Arab hatred of the distorted views of Matahari. Despite the feeling of the Arab community being somewhat calm about the title issue, PAI caused new turmoil. The purpose of this union was criticized from all sides, especially the recognition of Indonesia as a homeland has sparked anger in the Arab community. According to Pijper, many Arabs, even within the association itself, cannot accept the idea that people should exchange their Arab homeland for Indonesia's homeland.

Even though it reaped many lawsuits, gradually PAI gained more members or followers, especially young people from the Arab community who were born in Indonesia. Two-thirds of PAI members are young people from the sayid and sheikh groups. At the time of the fourth congress of the PAI in 1939, PAI already had 28 branches in the Dutch East Indies. According to Baswedan, the progress of PAI is too slow. Until 1936, PAI primarily pursued social, religious, and cultural goals. PAI publishes two magazines namely Sadar and Insaf. In the magazine contains the ideals and mission to the Arab community. With this union, PAI wanted to improve educational facilities among Arabs and asked to establish three Dutch-Arabic schools. PAI also established a youth section and women's association of Arab descent, which at that time was seen as a revolutionary act among Arabs. PAI also calls on Arabs to stop the practice of usury, even though the perpetrators are few, but it makes the image of the Arab community bad.

Feeling an increasingly important party, PAI became more and more politically active. Since 1936, PAI has openly joined the nationalist group. In 1936, PAI supported the famous petition filed by Soertardjo, an Indonesian member of the Voorksraad. The petition contains

\footnotetext{
${ }^{27}$ Algadri, Politik Belanda terhadap Islam dan Keturunan Arab di Indonesia, 161-63.
} 
a soft plea for a free and independent Indonesia in the context of Dutch-Indonesian unity. In 1937 PAI requested that the government adds more Arabs to the Volksraad, without reducing the number of representatives of other Asian foreign minorities. In addition, PAI encouraged equal rights for Peranakan Arabs and full-blooded Arabs, arguing that members of the second group should also be able to become subjects of the Dutch East Indies. In 1939, he joined with the Madjlis Islam A'laa Indonesia, a federation of Indonesian Islamic political associations, which proved that PAI was recognized by fellow nationalist organizations. In 1939-1940, PAI supported the actions to fight for a fully democratically elected Indonesian parliament launched by Gaboengan Politics Indonesia (GAPI), an alliance of Indonesian political parties ${ }^{28}$. The increase in PAI's political orientation can also be seen from the change in its name in 1940. Since then, PAI has become the abbreviation of the Indonesian Arab Party. The difference in PAI's attitude can be seen from their song lyrics as follows:

Indonesia is the motto of my unity

Indonesia is my homeland

Arab-Indonesian Union

The longer the brighter

We stay loyal

The more PAI develops, the more rejections occur. There is also a party that opposes the existence of PAI, namely the Indo-Arabisch Verbond founded by al-Amoedi, which he revived under the name Indo-Arabische Beweging (IAB, Indo-Arab Movement). This movement seeks to channel differences of opinion among Arabs who do not agree with the PAI, and to protect the interests of Arabs. They took a pro-Dutch position. Al-Amoedi opposed the PAI's nationalistic ideals and struggled to maintain Arab consciousness ${ }^{29}$. This association wanted to be part of the Dutch East Indies society, but at the same time wanted to maintain close non-political ties with the people of Hadramaut. In order to put an end to the dismal economic situation, which is especially the case for Peranakan Arabs after years of strife, the leaders recommended the establishment of specialized trade organizations. The

\footnotetext{
${ }^{28}$ Jan. M. Pluvier, Overzicht van de ontwikkeling der nationalistische bewerging in indonesie in de jaren 1930 tot 1942 (Den Hagg/Bandung: W. van Hoeven, 1953), 90-91.

${ }^{29}$ Ibid., 91.
} 
movement gained a following among conservative sayids, but never had politics. Political developments in Asia in the late 1930s favored the nationalistic movement.

\section{CONCLUSION}

The Arab community in Indonesia are Arabs who feel Yemeni or Hadramaut and not the Hejaz (original Arabs). They came to Indonesia for various purposes, namely trading, and also the unfavorable conditions that occurred in Hadramaut. The main destinations of the Hadramaut community are Aceh and Singapore. Aceh became the most important place for the Hadramaut community because of its strategic location for trade. The Hadramaut community is mostly traders. This area inhabited by Arab communities is along the coastline. They chose the coastal area because it was a suitable place for trading. Indirectly mixing Arabs and natives occurred. As a result of this marriage, the number of Arab communities in Indonesia has increased dramatically. This is also driven by the opening of the Suez Canal. In 1870 the Arabs numbered 13,000. In 1900 their number increased to 27,000 people and in 1920 reached 45,000 people, and reached its peak in 1930 when the number reached 71,335. Although reliable data were not available during later years, immigration activities are certain to have resulted in nearly 80,000 Arabs living in the colony at the start of the Japanese occupation (according to van der Kroef Indonesia accommodated 85,000 Arab inhabitants in 1952). In the Arab community there are often title battles between Sayid and Sheikh. Sayid still wants to maintain the Hadramaut culture. In addition, they still maintain Hadramaut as their homeland. In addition, the sheikh considers that their homeland is Indonesia. This title battle was won by the sheikhs in October 1934. Since then, the identity and social order in the previously closed Arab community has become more open to others.

The Arab community also has the Indonesian Arab Party (PAI) as a place to convey the aspirations and ideals of the Arab community. Although many are against it, but the goal of this party is the welfare of the Arab community itself. The founder of this party was A.R. Baswedan, a descendant of Hadrami who has an orientation towards the prosperity of the Arab community. Most of the Arab community in Indonesia in the 1930s identified Indonesia as their homeland. In addition, they also sympathized with the nationalist goals that developed during that period. This awareness and concern is the result of PAI's 
activities in collaboration with pro-nationalist organizations. In his view, PAI intends to remove barriers between the Arabs and the indigenous population. In the span of 42 years, the Hadramaut minority in the Dutch East Indies developed from an Arab-oriented community, but has Indonesian characteristics and became an Indonesian-oriented group with an Arab birthmark - coloring the period of the national movement and inseparable from their desire to be part of the community and Indonesian nation. This effort is solely to show his identity in the midst of Indonesian society. With this identity, the Arab community hopes to gain a position in Indonesian politics.

\section{REFERENCES}

Algadri, Hamid. Politik Belanda terhadap Islam dan Keturunan Arab di Indonesia. Jakarta: C.V. Haji Masagung, 1988.

Berg, L.W.C Ivan den. Handramut dan Koloni Arab di Nusantara. Jakarta: Seri INIS, 1989.

Engseng Ho. The Graves of tarim geneology and Mobility Across the Indian Ocean. California: California Press, 2006.

Faber, G.H. von. Nieuw Soerabaia, de Koopstand in de eerste Kwarteetuw Sadert Haren Instelling, 1906-193. Soerabaia: N.v. Boekhandel en Drukkerij II, van Ingen, 1993.

Gobee, E, dan C Adriaanse. Ambtelijke adviezen van C. Snouck Hurgronje. 33, 34, 35 ed. Vol. I, II, III. Den Hagg: Martinus Nijhoff, 1957.

Kartodirdjo, Sartono. Sejarah Indonesia Baru, 1500-1900: dari Emporium sampai Imperium. Vol. I. Jakarta: Gramedia, 1992.

Kroef, J.M van der. Indonesia in the Modern World. Vol. 1. Bandung: Mas Baru, 1954.

Kuntowijoyo. Metodologi Sejarah. Yogyakarta: Tiara Wacana, 1994.

Leur, J.C. van. Indonesian Trade and Society, Essay in Asia Social and Economic History. The Hague: van Hoeve Publisher Ltd., 1967.

Mustopo, M. Habib. Kebudayaan Islam di Jawa Timur, Kajian Beberapa Unsur Budaya Masa Peralihan. Yogyakarta: Penerbit Jendela, 2001.

Pluvier, Jan. M. Overzicht van de ontwikkeling der nationalistische bewerging in indonesie in de jaren 1930 tot 1942. Den Hagg/Bandung: W. van Hoeven, 1953.

Purwanto, Bambang. "Merajut Jaringan di Tengah Perubahan: Komunitas Ekonomi Muslim di Indonesia pada Masa Kolonial.” Yogyakarta: Fakultas Sastra UGM, 2000.

Ricklefs, M.C. Sejarah Indonesia Modern. Yogyakarta: Gadjah Mada University Press, 1991. 
ISLAH: Journal of Islamic Literature and History, Vol. 2, No. 2, December 2021: p. 81-101

Tjandrasasmita, Uka. Pertumbuhan dan perkembangan Kota-Kota Muslim di Indonesia. Kudus: Menara Kudus, 2000.

Touwen, Jaroen. Extremes in the Arcipelago, Trade and Economic Development in the Outer Islands of Indonesia, 1900-1942. Leiden: Rijksuniversiteit, 1997.

Volkstelling. Chineezen en andere Vreemde Oosterlingen In Nederlandsch-Indie. Vol. VII. Batavia: Lansdkrukkerij, 1930.

Wertheim, W.F. Masyarakat Indonesia dalam Transisi, Studi Perubahan Sosial. Yogyakarta: Tiara Wacana, 1999. 
Identity Politics: a Study of the Historicity Politics... (Bagus Prayogi \& M. Khoirul Hadi Al-Asyari) 